\title{
First report of garlic virus D in Allium stracheyi from India
}

\author{
Shahana Majumder ${ }^{1}$ (D) $\cdot$ Sneha Singh ${ }^{2} \cdot$ Jyoti Singh $^{2}$ \\ Received: 26 May 2020 / Accepted: 25 July 2020 / Published online: 11 August 2020 \\ (C) Società Italiana di Patologia Vegetale (S.I.Pa.V.) 2020
}

Keywords Allium stracheyi · Garlic virus D

Allium stracheyi, a member of the family Alliaceae, is a perennial herb which is used as culinary flavouring agent in Himalayan states of India, especially in Uttarakhand. It is known as Jambu or 'Jungli piyaz' in local dialect and is also known to have medicinal properties. This Allium species is distributed along Afghanistan, Pakistan and Western Himalayas to the Central Himalayas in sub-alpine zone (at a height of 3,000-4,800 m). As the vegetative propagated allium crops are known to be infected by multiple viruses (Van Dijk 1994), this study was undertaken to investigate the status of viral infection in A. stracheyi. Ten plants were collected in March of 2018 from two fields of Pithoragarh region of Uttarakhand. Preliminary electron microscopic examination of negatively stained leaf dip preparations revealed flexuous rod shaped particles of $\sim 800 \mathrm{~nm}$. Based on the length and morphology of the particles, samples were tested for the presence of onion yellow dwarf virus (OYDV), garlic common latent virus (GarCLV), shallot latent virus (SLV) and allexiviruses by reverse transcription (RT)-PCR, as described by Majumder and Baranwal (2014). OYDV, GarCLV and SLV were absent in the samples but allexiviruses could be detected in all the samples tested. BLASTn analysis of the consensus nucleotide sequence (GenBank accession No. MK501979) showed 88.8 to $93.3 \%$ identity with garlic virus D (GarV-D) sequences. To confirm the identity, RT-PCR was performed on eight allexivirus positive samples collected in April 2019 using the GarV-D specific primer pairs. Amplicons of the expected $\sim 870$ bp in size were obtained from all the samples tested. Direct sequencing of the PCR products from four samples produced 811-bp long nucleotide sequences. BLASTn analysis of the consensus nucleotide sequence (MT294142) showed 86.6-96.9\% identity with GarV-D sequences. To our knowledge, this is the first report of GarV-D infecting Allium stracheyi.

\section{Compliance with ethical standards}

Conflict of interest The authors declare that they have no conflict of interest.

\section{References}

Majumder S, Baranwal VK (2014) Simultaneous detection of four garlic viruses by multiplex reverse transcription PCR and their distribution in Indian garlic accessions. J Virol Methods 202:34-38

Van Dijk P (1994) Virus diseases of Allium species and prospects for their control. Acta Hortic 358:299-306

Publisher's note Springer Nature remains neutral with regard to jurisdictional claims in published maps and institutional affiliations.
Shahana Majumder

shahanamajumder@gmail.com

1 Department of Botany, School of Life Sciences, Mahatma Gandhi Central University, Motihari, Bihar, India

2 Department of Biotechnology, Sharda University, Knowledge Park III, G. Noida 201306, India 